\title{
PENGARUH PENAMBAHAN KUNYIT DAN JAHE DALAM RANSUM, TERHADAP ERITROSIT, LEUKOSIT DAN HEMOGLOBIN PUYUH JANTAN \\ (Effect of Addition Turmeric and Ginger Powder in The Ration onerythrocytes, leukocytes and haemoglobine of Male Quail)
}

\author{
Nella Nor N. S. ${ }^{1)}$, Muryani, R. $^{\text {)) }}$, dan Sunarti, D $^{3)}$ \\ ${ }^{1)}$ Mahasiswa Fakultas Peternakan dan Pertanian Universitas Diponegoro \\ Fakultas Peternakan dan Pertanian, Universitas Diponegoro \\ Jalan Prof. H Soedarto, SH, Tembalang 50275, Semarang \\ e-mail : nellaenes@gmail.com \\ ${ }^{2,3)}$ Staf Pengajar Fakultas Peternakan dan Pertanian Universitas Diponegoro \\ Fakultas Peternakan dan Pertanian, Universitas Diponegoro \\ Jalan Prof. H Soedarto, SH, Tembalang 50275, Semarang
}

Diterima : 12 Januari 2017 Disetujui : 19 Mei 2017

\begin{abstract}
ABSTRAK
Penelitian ini bertujuan untuk mengetahui pengaruh penambahan kunyit dan jahe dapat mempengaruhi eritrosit, leukosit dan hemoglobinpuyuh jantan.Materi yang digunakan dalam penelitian yaitu 100 ekor puyuh jantan jenis Coturnix-coturnix japonica

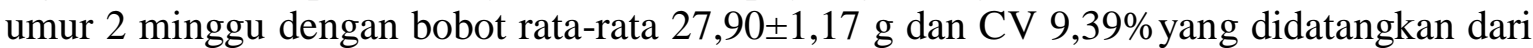
Ds. Pulosari Rt.05/Rw.01 Kecamatan Karang Tengah Demak.Penelitian dilakukan dengan menggunakan Rancangan Acak Lengakap (RAL) dengan 4 perlakuan yaitu T0 (Ransum Kontrol) T1 ( Ransum $+0,5 \%$ kunyit dan 0,25\% jahe), T2 (ransum $+1,00 \%$ kunyit dan $0,50 \%$ jahe), T3 (ransum $+1,50 \%$ kunyit dan 0,75 jahe), Perlakuan masing- masing diulang sebanyak 5 kali, dan setiap ulangan terdiri dari 5 ekor puyuh.Parameter yang diamati yaitu eritrosit, leukosit dan hemoglobin. Hasil penelitian menunjukkan bahwa penambahan kunyit dan jahe berpengaruh nyata $(\mathrm{P}<0,05)$ terhadapjumlah eritrosit dan kadar hemoglobin. Rataan jumlah eritrosit T0 : $3,47 \times 10^{6} / \mathrm{mm}^{3} \pm 0,12$, T1 : $3,32 \times 10^{6} / \mathrm{mm}^{3} \pm 0,12$, T2 : $3,84 \times 10^{6} / \mathrm{mm}^{3} \pm 0,12$, T3 : $3,83 \times 10^{6} / \mathrm{mm}^{3} \pm 0,12$, rataan kadar hemoglobin T0 : 7,31/ $\pm \pm 0,28, \mathrm{~T} 1: 8,63 \mathrm{~g} / \mathrm{dl} \pm 0,28, \mathrm{~T} 2: 8,61 \mathrm{~g} / \mathrm{dl} \pm 0,28, \mathrm{~T} 3: 8,56$ $\mathrm{g} / \mathrm{dl} \pm 0,28$.Penambahan kunyit dan jahe tidak berpengaruh nyata $(\mathrm{P} \geq 0,05)$ terhadap leukosit

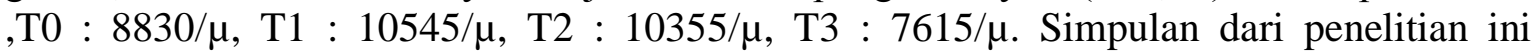
penambahan tepung kunyit $1 \%$ dan jahe $0,5 \%$, merupakan level yang terbaik dan mampu meningkatkan jumlah eritrosit dan kadar hemoglobin pada puyuh jantan.
\end{abstract}

Kata kunci: kunyit, jahe, eritrosit, leukosit, hemoglobin.

\section{ABSTRACT}

The purpose of this study determine the effect addition turmeric and ginger may affect erythrocytes, leukocytes and haemoglobinequail male. Materials used in the study of 100 male quails tail-coturnix japonica types Coturnix age of 2 weeks with an average weight of 27.90 $\pm 1.17 \mathrm{~g}$ and $9.39 \% \mathrm{CV}$ that from Ds. Pulosari Rt.05 / Rw.01 Karang Tengah 
District Demak. The study was conducted using Completely Randomized Design (CRD) with 4 treatments, TO (Ration Control) $\mathrm{T1}$ (ration $+0.5 \% 0.25 \%$ turmeric and ginger), T2 (feed $+1.00 \%$ and $0.50 \%$ turmeric ginger), T3 (feed $+1.50 \% 0.75$ turmeric and ginger), each treatment was repeated 5 times, and each replication consisted of 5 mice quail. Parameters observed that theerythrocytes, leukocytes and haemoglobine. The results showed that the addition of turmeric and ginger significant $(P<0.05)$ erythrocytes and haemoglobine. The averageerythrocytesT0 : 3,47 $\times 10^{6} / \mathrm{mm}^{3} \pm 0,12, \mathrm{T1}: 3,32 \times 10^{6} / \mathrm{mm}^{3} \pm 0,12$, $T 2: 3,84 \times 10^{6} / \mathrm{mm}^{3} \pm 0,12, \mathrm{T3}: 3,83 \times 10^{6} / \mathrm{mm}^{3} \pm 0,12$, the average haemoglobineT0 : 7,31 $\mathrm{g} / \mathrm{dl} \pm 0,28, T 1: 8,63 \mathrm{~g} / \mathrm{dl} \pm 0,28, T 2: 8,61 \mathrm{~g} / \mathrm{dl} \pm 0,28, T 3: 8,56 \mathrm{~g} / \mathrm{dl} \pm 0,28$. The addition of turmeric and ginger no significant effect $(P \geq 0,05)$ onleukocytes, T0 : 8830/ $\mu, T 1$ : $10545 / \mu, T 2: 10355 / \mu, T 3: 7615 / \mu$.The conclusions of this study the addition of $1 \%$ turmeric powder and ginger 0.5\%, the best level and be able to increase the number of erythrocytes and hemoglobin concentration in male quail.

Keywords: turmeric, ginger,erythrocytes, leukocytes and haemoglobine.

\section{PENDAHULUAN}

Populasi puyuh yang meningkat dari tahun ke tahun membuktikan bahwa puyuh merupakan salah satu komoditi unggas yang semakin populer di masyarakat.Tahun 2009 populasi puyuh mencapai 4.133.926, tahun 2010 jumlah puyuh mencapai 4.130.035, tahun selanjutnya 2011 mencapai 4.636.460, tahun 2012 mencapai 4.827.825 dan tahun 2013 mencapai 4.741.170 (Badan Statistik, 2014). Peningkatan populasi puyuh mengindikasikan banyaknya masyarakat yang berminat untuk memelihara puyuh dan mengonsumsi produk-produk yang dihasilkan dari puyuh, khususnya daging dan telur yang memiliki banyak kandungan gizi. Hasil pemanfaatan puyuh adalah daging dan telur. Pada industri peternakan puyuh yang dimanfaatkan hanya puyuh betina untuk diambil daging dan telur sedangkan puyuh jantan kurang dimanfaatkan dagingnya. Dengan pemberian ransum dan perlakuan yang tepat puyuh tidak kalah dengan nutrisi yang terkandung dalam unggas lainnya.

Kunyit dan jahe dapat digunakan sebagai bahan tambahan dalam pakan, mudah di cari, harga yang relatif murah. Kedua bahan tersebut tidak mengandung toksik sehingga aman untuk dicampur, kelebihan dicampur menghasilkan antioksidan yang lebih banyak dibandingkan secara terpisah dan banyak manfaat yang terkandung didalamnya yaitu memiliki aktivitas antioksidan, antiinflamasi, antiviral, antiprotozoa, antifungal, hepatoprotektor, antibakteri.

Minyak atsiri yang berperan sebagai antibakteri sehingga membantu meningkatkan daya tahan tubuh (leukosit) puyuh terhadap serangan bakteri patogen, merangsang dinding kantong empedu mengeluarkan cairannya, merangsang keluar getah pankreas, membantu penyerapan nutrisi secara maksimal dalam usus sehingga dapat membantu pembentukan sel darah merah (eritrosit) yang dibantu oleh hemoglobin. Senyawa kurkumin mempunyai aktivitas antioksidan dan meningkatkan metabolisme nutrien dalam tubuh. Metabolisme seluler yang meningkat akan meningkatkan oksigen yang dibutuhkan oleh hemoglobin dalam pembentukan eritrosit.

Penambahan campuran jahe dan kunyit dalam ransum mampu meningkatkan aktivitas antioksidan dibandingkan bila dipergunakan secara terpisah, sehingga pencampuran kunyit dan jahe diharapkan 
mampu memberikan kombinasi antioksidan dengan aktivitas lebih tinggi dibandingkan bila hanya digunakan secara terpisah. Harapannya campuran kunyit dan jahe mampu meningkatkan jumlah eritrosit, kadar hemoglobin dan jumlah leukosit dalam kisaran rata-rata.

Penelitian ini dilaksanakan untuk mengetahui pengaruh penambahan kunyit dan jahe terhadap eritrosit, leukosit dan hemoglobin puyuh jantan diharapkan memberi pengaruh positif. Tujuan penelitian adalah untuk mengetahui dan mengkaji pengaruh penambahan kunyit dan jahe dalam ransum terhadaperitrosit, leukosit dan hemoglobin puyuh jantan. Manfaat yang diperoleh dari penelitian adalah dapat membantu peternak dan masyarakat menggunakan kunyit dan jahesebagai bahan aditif untuk menjaga keseimbangan eritrosit, leukosit dan hemoglobin puyuh jantan.

\section{MATERI DAN METODE}

\section{Materi}

Penelitian dengan judul "Pengaruh Penambahan Kunyit dan Jahe dalam Ransum, Terhadap eritrosit, leukosit dan hemoglobinPuyuh Jantan" dilaksanakan pada bulan Juni - Juli 2016, di kandang Fakultas Peternakan dan Pertanian, Universitas Diponegoro, Semarang.

Materi yang digunakan dalam penelitian yaitu 100 ekor puyuh jantan jenis Coturnix-coturnix japonica umur 2 minggu dengan bobot rata-rata $27,90 \pm 1,17 \mathrm{~g}$ dan CV 9,39\%, yang didatangkan dari Ds. Pulosari Rt.05/Rw.01 Kecamatan Karang Tengah Demak.Ransum puyuh, destan, sekam, kapur gamping, detergen,tepung kunyit dan tepung jahe.Alat yang digunakan, kandang battery, timbangan, termometer, hygrometer, nampan, pisau, cuter, label, plastik, trash bag, gunting, panci, lakban, alat tulis, tirai, koran,, tempat makan dan tempat minum, kuas, sprayer, stop kontak, alat kebersihan, dan lampu.

\section{Metode}

Penelitian ini terdiri dari dua tahap, yaitu tahap persiapan, sebelum digunakan, kandang terlebih dahulu didesinfektan dengan detergen dan destan, lalu kapur gamping, agar tidak timbul mikroorganisme diberi interval 3 hari. Alat-alat yang digunakan dipersiapkan seperti, alat kebersihan kandang, termometer untuk ukur suhu, higrometer, lampu untuk pencahayaan, tempat pakan dan tempat minum.Tahap pesiapan ternak, puyuh jantan umur 2 minggu bobot rata-rata $27,90 \pm 1,17$ g dan CV 9,39\% yang didatangkan dari Demak dipersiapkan untuk pemeliharaan sesuai waktu rencana penelitian.

Metode yang akan digunakan dalam penelitian ini adalah 4 perlakuan yaitu T0 (Ransum Kontrol) T1 (Ransum + 0,5\% kunyit dan $0,25 \%$ jahe), T2 (ransum + $1,00 \%$ kunyit dan $0,50 \%$ jahe), T3 (ransum $+1,50 \%$ kunyit dan 0,75 jahe), Perlakuan masing- masing diulang sebanyak 5 kali, dan setiap ulangan terdiri dari 5 ekor puyuh selama 6 minggu. Setiap hari diberikan pakan rutin 2 kali sehari dan minum. Metode pengambilan data, bobot potong puyuh jantan diambil 1-2 ekor/unit percobaan dari setiap perlakuan pada akhir pemeliharaan, ditimbang bobot hidupnya, kemudian puyuh dipotong. Setelah dipotong, dikeluarkan darahnya, dimasukkan kedalam EDTA kemudian dianalisis. Penelitian dilakukan dengan menggunakan Rancangan Acak Lengakap (RAL) dengan 4 perlakuan, jika hasil signifikan dilanjutkan uji DUNCAN. 
Tabel 1. Kandungan Nutrisi Bahan Pakan Penyusun Ransum dalam Berat Kering

\begin{tabular}{lllllll} 
Bahan Pakan & EM (kkal/kg) & PK & LK & SK & Ca & P \\
\hline Jagung kuning & 3321 & & $------------(\%)----------$ & \\
Bekatul & 2.887 & 12 & 10,7 & 5,2 & 0,61 & 0,81 \\
Bungkil kedelai & 2.216 & 44,62 & 1,11 & 4,4 & 0,19 & 0,97 \\
Tepung ikan & 2.219 & 72 & 0,2 & 0,3 & 7,9 & 3,6 \\
Kunyit & 248,77 & 9,05 & 4,16 & 17,85 & 0 & 0 \\
Jahe & 2671,42 & 9,40 & 6,39 & 16,30 & 0 & 0 \\
\hline Sune & & & & 0,83 & 0,02 & 0,12 \\
\hline
\end{tabular}

Sumber : Hasil Analisis Proksimat Laboratorium Ilmu Nutrisi dan Pakan, Universitas Diponegoro Semarang (2016).

Tabel 2. Susunan Ransum dan Kandungan Nutrisi Ransum Perlakuan

\begin{tabular}{lllll}
\hline \multirow{2}{*}{ Bahan Pakan } & \multicolumn{4}{c}{ Ransum Perlakuan } \\
\cline { 2 - 5 } Jagung & T0 & T1 & T2 & T3 \\
Bungkil Kedelai & 51 & 51 & 51 & 51 \\
Bekatul & 18 & 18 & 18 & 18 \\
Tepung Ikan & 17 & 17 & 17 & 17 \\
Premix & 12 & 12 & 12 & 12 \\
Kunyit & 2 & 2 & 2 & 2 \\
Jahe & 0 & 0,50 & 1,00 & 1,50 \\
Total & 0 & 0,25 & 0,50 & 0,75 \\
\hline Kandungan Nutrien : & 100 & 100,75 & 101,50 & 102,25 \\
\hline & & & & \\
Protein Kasar (\%) & 23,25 & 23,15 & 23,04 & 22,81 \\
ME (kkal/kg) & 2849,66 & 2847,42 & 2845,22 & 2843,04 \\
Serat Kasar (\%) & 2,14 & 2,25 & 2,36 & 2,47 \\
Lemak Kasar (\%) & 2,45 & 2,46 & 2,48 & 2,50 \\
Air (\%) & 1,09 & 1,08 & 1,07 & 1,07 \\
Abu (\%) & 0,80 & 0,79 & 0,79 & 0,78 \\
\hline Keterangan & & &
\end{tabular}

Keterangan :*Kandungan Nutrisi Ransum Puyuh Jantan.

Perhitungan parameter-parameter yang digunakan dengan rumus sebagai berikut.

1. Eritrosit

Perhitungan eritrosit dapat dihitung dengan cara :

Sel-sel yang terhitung $\mathrm{x} 10(0,1 \mathrm{~mm}$ di dalam) x $5\left(1 / 5\right.$ dari $\left.1 \mathrm{~mm}^{3}\right) \times 200(1$ :

200) $=$ jumlah eritrosit per $\mathrm{mm}^{3}$.

2. Leukosit

Perhitungan leukosit dapat dihitung

dengan cara :
Cari 9 ruang besar, kemudian hitung Jumlah leukosit pada 4 ruang besar dari 9 ruang sebelumnya. Hasil penghitungan dikalikan 50

3. Hemoglobin : Pemeriksaan dengan spektrofotometer 
HASIL DAN PEMBAHASAN

Pengaruh Penambahan Kunyit dan Jahe Terhadap Eritrosit, Leukosit dan Hemoglobin Puyuh Jantan.

Hasil penelitian tentang pengaruh penambahan kunyit dan jahe terhadap eritrosit, leukosit dan hemoglobin dapat dilihat pada Tabel 1. Hasil analisis ragam menunjukkan bahwa perlakuan penambahan kunyit dan jahe berpengaruh nyata $(\mathrm{P}<0,05)$ terhadap jumlah eritrosit, kadar hemoglobin dan tidak berpengaruh nyata $(\mathrm{P}>0,05)$ terhadap leukosit.

Tabel 3. Rataan jumlah eritrosit, jumlah leukosit dan kadar hemoglobin puyuh jantan umur 6 minggu.

\begin{tabular}{cccc}
\hline Perlakuan & Eritrosit & $\begin{array}{c}\text { Leukosit } \\
/ \mu 1\end{array}$ & $\begin{array}{c}\text { Hemoglobin } \\
\mathrm{g} / \mathrm{dl}\end{array}$ \\
\hline T0 & $10^{6} / \mathrm{mm}^{3}$ & 8830 & $7,31^{\mathrm{b}}$ \\
T1 & $3,47^{\mathrm{ab}}$ & 10545 & $8,63^{\mathrm{a}}$ \\
T2 & $3,32^{\mathrm{b}}$ & 10355 & $8,61^{\mathrm{ab}}$ \\
T3 & $3,84^{\mathrm{a}}$ & 7615 & $8,56^{\mathrm{ab}}$ \\
\hline
\end{tabular}

Keterangan : huruf yang berbeda dalam kolom menunjukkan berbeda nyata $\quad(\mathrm{P}<0,05)$

Pengaruh Penambahan Kunyit dan Jahe Terhadap Eritrosit Puyuh Jantan

Berdasarkan uji statistik jumlah eritrosit pada puyuh jantan berbeda nyata $(\mathrm{P}<0,05)$, akibat pemberian kunyit dan jahe (perlakuan). Jumlah tertinggi pada perlakuan yaitu $\mathrm{T} 2 ; 3,84 \times 10^{6} / \mathrm{mm}^{3}$, T3; $3,83 \times 10^{6} / \mathrm{mm}^{3}$, diikuti

T0;

$3,47 \times 10^{6} / \mathrm{mm}^{3}$ dan terakhir T1 ; $3,32 \times 10^{6} / \mathrm{mm}^{3}$. Rataan jumlah eritrosit pada penelitian pada kisaran 3,32 - 3,84 $\mathrm{x} 10^{6} / \mathrm{mm}^{3}$. Hal ini tidak jauh berbeda dengan penelitian Piliang et al.,(2009) yang menyatakan bahwa jumlah eritrosit puyuh $3-3,78 \times 10^{6} / \mathrm{mm}^{3}$. Kusumawati (2000) menyatakan bahwa rata rata sel darah merah pada unggas 1,25 $4,50 \times 10^{6} / \mathrm{mm}^{3}$.

Hasil rataan tertinggi yang berpengaruh terhadap eritrosit yaitu $\mathrm{T} 2$ dan T3 $\left(3,84 \times 10^{6} / \mathrm{mm} 3\right.$ dan $\left.3,83 \times 10^{6} / \mathrm{mm} 3\right)$. Kandungan kunyit dan jahe memiliki senyawa yang bersifat antioksidan yaitu flavonoid, minyak atsiri, kurkumin, fenol, yang dapat melawan radikal bebas pada saat eritropoesis. Wijayakusuma (2007) menyatakan bahwa kunyit dan jahe mampu meningkatkan efek antioksidan bila digunakan secara bersamaan, dibanding secara terpisah. Kriswanto (2011) menyatakan bahwa perlakuan campuran kunyit dan jahe mempunyai aktivitas antioksidan tinggi yang disebabkan kurkumin, minyak atisri, detoksikurkumin, flavonoid, sehingga semakin banyak variasi perlakuannya semakin tinggi pula antioksidan yang dihasilkan.

Kandungan kunyit dan jahe dapat meningkatkan aktivitas dalam saluran pencernaan, merangsang keluarnya asam proventrikulus, kemudian bercampur dengan enzim-enzim seperti lipase, amilase , laktase yang akan dipecah menjadi partikel sederhana. Masuk ke duodenum, adanya kunyit dan jahe dapat merangsang garam-garam empedu keluar semakin banyak sehingga dapat merangsang pangkreas mengeluarkan enzim, selanjutnya menuju illeum terjadi penyerapan nutrisi secara sempurna kemudian dibawah oleh darah menuju ke sel dan jaringan. Hal ini sesuai pendapat Purwati (2008), kurkumin yang terkandung dalam kunyit dapat meningkatkan nafsu makan karena dapat 
proventrikulus, sehingga meningkatkan aktivitas pencernaan. Menurut Darwis et al.,(1991), minyak atsiri dalam kunyit dan jahe berfungsi merangsang keluarnya asam proventrikulus sehingga mengurangi kinerja usus yang berat.

\section{Pengaruh Penambahan Kunyit dan Jahe Terhadap Leukosit Puyuh Jantan}

Berdasarkan uji statistik jumlah leukosit pada puyuh jantan tidak berbeda nyata $(\mathrm{P}>0,05)$, akibat pemberian kunyit dan jahe (perlakuan). Jumlah tertinggi pada

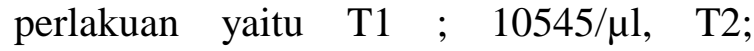
10355/ $\mu 1$, diikuti T0; 8830/ $\mu 1$ dan terakhir T3; 7615/ $\mu 1$. Hal ini tidak sesuai pendapat Julendra et al., (2010) bahwa rataan jumlah leukosit unggas antara 12000-30.000/ $\mu 1$. Menurut sturkie (1976) kisaran normal jumlah leukosit burung puyuh adalah 20000-40000/ $\mu 1$.

Leukosit bersangkutan dalam komponen darah yang dapat menjaga ketahanan tubuh, sedangkan hemoglobin bagian dari eritrosit yang membantu dalam proses pembentukan sel darah merah, sehingga dalam proses pembentukan sel darah merah membutuhkan ketahanan tubuh yang kuat. Leukosit, eritrosit dan hemoglobin sama-sama dibentuk dalam sum-sum tulang belakang. Menurut Guyton (1983) bahwa, leukosit adalah sistem pertahanan tubuh dan dibentuk dalam sumsum tulang belakang. Sharmin (2004) menyatakan bahwa pembentukan sel darah merah dan sel darah putih terletak pada sum-sum tulang belakang.

Penambahan kunyit dan jahe tidak berpengaruh nyata $(\mathrm{P}>0,05)$ terhadap leukosit puyuh jantan. Berdasarkan tabel 1 . Jumlah tertinggi leukosit puyuh terdapat pada T1 dan T2 tetapi berada dalam kisaran sedikit dibawah rata-rata. Diduga perlakuan

yang diberikan tidak memberikan pengaruh terhadap leukosit. Faktor yang mempengaruhi pembentukan leukosit pakan yang diberikan pada puyuh, stres dan keadaan lingkungan kandang. Hal ini sesuai pendapat Guyton dan Hall (1997) bahwa jumlah sel darah putih dipengaruhi oleh stres, lingkungan, aktivitas fisiologis, status gizi, panas tubuh, dan umur. Isroli et.al, (2009) menyatakan bahwa tidak adanya perbedaan tersebut berarti tidak ada perbedaan kondisi (perbedaan perlawanan terhadap benda asing) pada tubuh unggas tersebut.

Penambahan tepung kunyit dan jahe dalam ransum tidak memberikan pengaruh terhadap leukosit. Dosis yang tidak memberikan pengaruh terhadap jumlah leukosit dan diduga ada masalah terhadap sumsum tulang yang menyebabkan sel darah putih menurun. Menurut Saraswati (2006) bahwa pemberian limbah padat kunyit sampai kadar 20\% dalam pakan tidak menyebabkan ayam stress yang dapat berpengaruh terhadap jumlah leukosit. Sherwood (1996) menyatakan bahwa penurunan jumlah leukosit dapat disebakan karena adanya masalah dengan sumsum tulang sehingga terjadi penurunan pembentukan fagosit profesional, yang menyebabkan penurunan bermakna kemampuan pertahanan tubuh terhadap mikroorganisme invasif.

\section{Pengaruh Penambahan Kunyit dan Jahe Terhadap Hemoglobin Puyuh Jantan.}

Berdasarkan uji statistik kadar hemoglobin pada puyuh jantan berbeda nyata $(\mathrm{P}<0,05)$, akibat pemberian kunyit dan jahe (perlakuan). Jumlah tertinggi pada perlakuan yaitu T1 ;8,63g/dl, T2; 8,61g/dl, diikuti T3; 8,56g/dl dan terakhir T0 ; 7,31g/dl. Pilliang et al., (2009) menyatakan bahwa kadar hemoglobinrata-rata pada 
puyuh adalah 10-13 g/ $\mu \mathrm{I}$. menurut Jain (1993) bahwa kadar normal hemoglobin puyuh 7,0 - 13,0 g/ $\mu \mathrm{I}$.

Berdasarkan penelitian hemoglobin berpengaruh nyata $(\mathrm{P}<0,05)$, disebabkan kandungan kunyit dan jahe mengandung zat besi yang dibutuhkan oleh hemoglobin dalam pembentukan molekul heme. Besi heme diolah di proventikulus, karena pengaruh asam proventrikulus, maka besi dilebas dari ikatannya dengan senyawa lain, kemudian terjadi reduksi dari besi dan diserap oleh duodenum, kemudian dalam darah diikat oleh opotransferin menjadi transferin dan akan melepas besi yang siap digunakan hemoglobin dalam proses eritropoesis. Guyton (1997) menyatakan bahwa, sintesis hemoglobin sangat dipengaruhi oleh kadar besi yang penting dalam pembentukan molekul heme. Menurut Oppusunggu (2009), zat besi mempunyai fungsi untuk pembentukan hemoglobin, mineral dan pembentukan enzim.

Pembentukan

hemoglobin

dipengaruhi oleh protein. Protein dikonsumsi melalui pakan, masuk kedalam tubuh menuju ke pencernaan dan berubah menjadi asam amino yang di transportasikan oleh plasma darah melalui sistem sirkulasi menuju ke sel dan jaringan. Asam amino digunakan dipergunakan untuk pertumbuhan, perkembangan sel darah merah, transpor oksigen dan karbondioksida ke paru paru. Menurut Schmidt dan Nelson (1990), kunyit dan jahe mampu mempertahankan protein dan asam amino dalam tubuh.

Kunyit dan jahe mengandung senyawa yang berifat antioksidan seperti stilbena, asam-asam galat, elagat, kumarat, minyak atsiri, flavonoid, kurkumin, fenol yang memiliki kemampuan melawan radikal bebas, antioksidan bekerja dengan cara menetralkan radikal bebas, kemampuan antioksidan tersebut menjadi tidak aktif setelah menetralkan, sehingga perlu memasok tubuh setiap hari dengan antioksidan. Kinsella et al., (1993) menyatakan bahwa, Senyawa fenol yang terdapat pada kunyit dan jahe bisa berfungsi sebagai antioksidan karena kemampuannya melawan radikal bebas. Menurut Kriswanto (2011), kunyit dan jahe memiliki aktivitas antioksidan seperi kurkumin dan detoksikurkumin yang antioksidannya tinggi, sehingga semakin besar variasi perlakuannya semakin tinggi pula aktivitas antioksidan yang dihasilkannya.

Kunyit dan jahe mengandung antioksidan yang dibutuhkan oleh tubuh untuk melawan radikal bebas yang disebabkan oleh bakteri dan mikroorganisme, salah satu penurunan kadar hemoglobin disebabkan oleh adanya mikroorganisme, yang berakibat kemampuan kapasitas pengangkutan oksigen dari darah berkurang, dengan adanya antioksidan dapat melawan mikroorganisme, sehingga kerja hemoglobin tidak terhambat. Menurut Sharmin (2004) bahwa, reaksi oksidatif dapat merusak hemoglobin, enzim dan lipid membran. Oppusanggu (2009) menyatakan bahwa, hemoglobin bertindak sebagai unit pembawa oksigen dari paru-paru ke sel.

\section{KESIMPULAN}

Penambahan tepung kunyit $1 \%$ dan jahe $0,5 \%$, merupakan kombinasi terbaik untuk meningkatkan jumlah eritrosit dan kadar hemoglobin pada puyuh jantan

\section{DAFTAR PUSTAKA}

Darwis, S.N., A.M Indo dan S. Hasiah. 1991. Tanaman Obat Family 
Zingiberaciae. Pusat Penelitian dan Pengembangan Tanaman Industry, Bogor.

Guyton, A. C. 1983. Fisiologi Kedokteran. Penerjemah: Dharma A. dan Lukito. Terjemahan dari: Medical Physiology. EGC. Jakarta.

Guyton, A. C., Hall J. E. 1997. Buku Ajar Fisiologi Kedokteran. Edisi 9. EGC, Jakarta.

Isroli, Susansi S, Widiastuti E, Yudiarti T, dan Sugiharto. 2009. Observasi Beberapa Variabel Hematologis Ayam Kedu pada Pemeliharaan Intensif. Seminar Nasional Kebangkitan Peternakan. Universitas Diponegoro.

Jain, N.C. 1993. Essential of Veterinary Hematology. Lea \& Febiger: Philadelpia.

Julendra. H., Zuprizal dan Supadmo. 2010. Penggunaan Tepung Cacing (Lubricus rubellus)sebagai Aditif Pakan terhadap Penampilan Produksi Ayam Pedaging, Profil Darah dan Kecernaan Protein. Bulletin Peternakan Vo.34 (1) : 2129.

Kinsella, J.E. Frankel, E. German, B. And Kanmer, J. 1993. Possible Mekanismefor the Protective role of Antioxidants in Wine and Plant Foods J Food Technology. 4:5-89.

Kriswanto, M. 2011. Tanaman Berkhasiat Antioksidan. PenebarSwadaya. Jakarta.

Kusumawati, D.S.U. 2000. Bersahabat Dengan Hewan Coba. Gadjah Mada University Press, Yogyakarta.
Oppusunggu, Riris. 2009. Pengaruh Pemberian Tablet Tambah Darah (Fe) terhadap Produktivitas Kerja Wanita Pensortir Daun Tembakau di PT.X Kabupaten Deli Serdang. Tesis. USU: Medan.

Piliang, W. G., D. A. Astuti, dan W. Hermana. 2009. Pengkayaan produk puyuh melalui pemanfaatan pakan lokal yang mengandung antioksidan dan mineral sebagai alternatif penyediaan protein hewani bergizi tinggi. Dalam: Prosiding seminar hasil-hasil penelitian IPB Bogor. Hal: 27-39.

Purwanti, S. 2008. Kajian Efektifitas Pemberian Kunyit, Bawang Putih , Mineral ZinkTerhadap Performa, Kadar Lemak, Kolesterol Broiler. Tesis. Institut Pertanian Bogor, Bogor.

Saraswati, T.R. 2006. Buletin Anatomi dan Fisiologi. Penambahan Limbah Padat Kunyit (Curcuma Domestica) pada Ransum Ayam dan Pengaruhnya terhadap Status Darah dan Hepar Ayam (Gallus sp). Laboratorium Biologi Struktur dan Fungsi Hewan Jurusan Biologi FMIPA Universitas Diponegoro.

Schmidt, W. and Nelson, B. 1990. Animal Physiology. Harper Collins Publisher, New York.

Sharmin M.L. dan Myenuddin M. 2004. Hematological Values of The Indigenous Chickens. Bangl. J. Vet. Med. 2(2): 163-164.

Sherwood, Lauralee. 1996. Fisiologi Manusia dari Sel ke Sistem. Brahm $\mathrm{U}$, penerjemah; Santoso BI, editor. Jakarta (ID): EGC. Terjemahan dari: 
Human Physiology: From Cells to

Systems. Ed ke-2.

Statistik Peternakan. 2014. Dinas

Peternakan dan Kesehatan Hewan Jawa Tengah.

Sturkie, P. D. 1976. Blood : Physical Characteristics, Formed, Elements, Hemoglobin, and Coagulan in Avian Physiology. Thirt Edition. Springer Verlag, New York.

Wijayakusuma, H.M. 2007. Tanaman

Berkhasiat Obat di Indonesia. Jilid

IV. Cetakan II. Jakarta: Pustaka

Kartini. Hal. 7. 